\title{
Parosteal lipoma mimicking a breast tumor
}

\author{
Lisa Suyama, Ako Itoh
}

Department of Breast and Thyroid Surgery, Hitachi General Hospital, Hitachi, Ibaraki, Japan

\section{Correspondence to}

Dr Lisa Suyama,

lisa.mizutani@gmail.com

Accepted 4 August 2017

\section{DESCRIPTION}

Parosteal lipoma is a rare benign tumour that is composed mainly of mature adipose tissue, and is contiguous to the periosteum of the underlying bone. ${ }^{1}$ Most parosteal lipomas are asymptomatic, but some may present motor and/or sensory deficits. $^{2}$

A woman was seen in our office complaining a left breast tumour. The woman first noticed the tumour several years ago and underwent breast cancer screening annually but was never required for further evaluation. The tumour was slowly growing, and was associated with pain when lying in a prone position. On physical examination, a soft tumour measuring $9 \mathrm{~cm}$ could be felt in the lower-inner quadrant of the left breast, and was firmly fixed to the chest wall. Mammogram showed a well-circumscribed, smooth, lipomatous mass containing a coral-like calcification (figure 1). Breast ultrasonogram showed a large lipomatous nodule near the caudal end of the mammary gland. Although the lesion could not be detected clearly on a chest X-ray, a CT scan showed an osteoblastic portion arising from the fifth rib, and was surrounded by a capsulated lipoma. The lipoma was displacing the mammary gland upwards (figure 2). An MRI scan showed a parosteal lipoma, with no malignant findings. The patient wished to remove the tumour, and she underwent a tumour extirpation. The base of the ossified area was removed using a wire saw. A specimen mammography was taken to determine the adequacy of excision. On histological examination, the mass was composed of mature lipocytes containing a bony proliferation and was consistent with that of a parosteal lipoma.

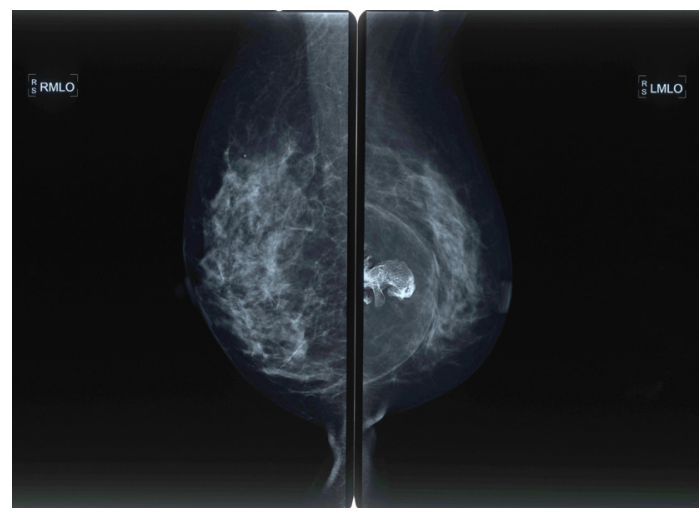

Figure 1 Mammogram shows a well-circumscribed, smooth, lipomatous mass containing a coral-like calcification.

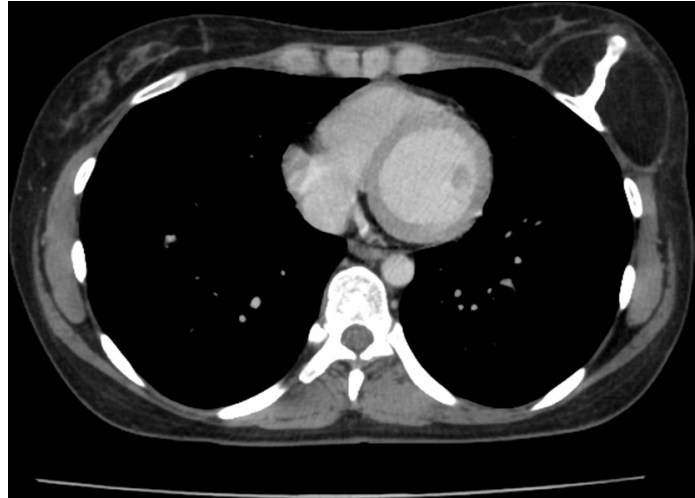

Figure 2 A chest CT scan shows an osteoblastic portion exceeding from the fifth rib, and is surrounded by a capsulated lipoma.

The patient's pain relieved soon after the surgery and remains well at present.

Learning points

- A parosteal lipoma could arise from the rib and could mimic a breast tumour in female patients.

- Motor and/or sensory disturbances from nerve compression may occur; surgical removal of the parosteal lipoma will immediately relieve pain. ${ }^{2}$

- If no surgery is done, the pain may remain and the tumour may grow larger leading to irreversible atrophic change of muscles; however, there are no reports of malignant transformation of the tumour.

Contributors LS conceived of, planned, conducted and reported the study. Al helped to initiate the study design and interpret the data. All authors contributed to refinement of the study protocol and approved the final manuscript.

Competing interests None declared.

Patient consent Detail has been removed from this case description to ensure anonymity. The editors and reviewers have seen the detailed information available and are satisfied that the information backs up the case the authors are making.

Provenance and peer review Not commissioned; externally peer reviewed.

(c) BMJ Publishing Group Ltd (unless otherwise stated in the text of the article) 2017. All rights reserved. No commercial use is permitted unless otherwise expressly granted.

\section{REFERENCES}

1 Jang SM, Na W, Jun YJ, et al. Parosteal lipoma of the rib. Ann Thorac Surg 2009;87:316-8

2 Kim HK, Choi YH, Cho YH, et al. Intercostal neuralgia caused by a parosteal lipoma of the rib. Ann Thorac Surg 2006;81:1901-3. 
Copyright 2017 BMJ Publishing Group. All rights reserved. For permission to reuse any of this content visit http://group.bmj.com/group/rights-licensing/permissions.

BMJ Case Report Fellows may re-use this article for personal use and teaching without any further permission.

Become a Fellow of BMJ Case Reports today and you can:

- Submit as many cases as you like

- Enjoy fast sympathetic peer review and rapid publication of accepted articles

Access all the published articles

- Re-use any of the published material for personal use and teaching without further permission

For information on Institutional Fellowships contact consortiasales@bmjgroup.com

Visit casereports.bmj.com for more articles like this and to become a Fellow 